\title{
QRI 8032
}

Bureau of Mines Report of Investigations $/ 1975$

RECEIVED BY TIS JUL 141975

Substitution of Phosphate Slime for Bentonite in Geothermal Well Drilling Fluids

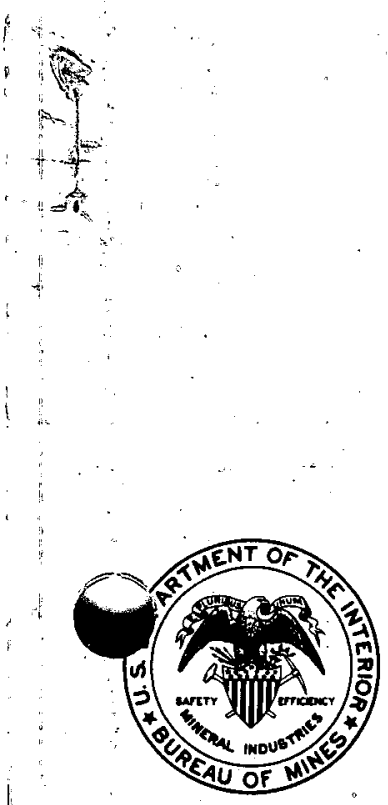

UNITED STATES DEPARTMENT OF THE INTERIOR 


\section{DISCLAIMER}

This report was prepared as an account of work sponsored by an agency of the United States Government. Neither the United States Government nor any agency Thereof, nor any of their employees, makes any warranty, express or implied, or assumes any legal liability or responsibility for the accuracy, completeness, or usefulness of any information, apparatus, product, or process disclosed, or represents that its use would not infringe privately owned rights. Reference herein to any specific commercial product, process, or service by trade name, trademark, manufacturer, or otherwise does not necessarily constitute or imply its endorsement, recommendation, or favoring by the United States Government or any agency thereof. The views and opinions of authors expressed herein do not necessarily state or reflect those of the United States Government or any agency thereof. 


\section{DISCLAIMER}

Portions of this document may be illegible in electronic image products. Images are produced from the best available original document. 
Report of Investigations 8032

\section{Substitution of Phosphate Slime for Bentonite in Geothermal Well Drilling Fluids}

By Alan H. Goode and Leon Y. Sadler III

$\checkmark$ Tuscaloosa Metallurgy Research Laboratory, Tuscaloosa, Ala.

\section{UNITED STATES DEPARTMENT OF THE INTERIOR}

Rogers C. B. Morton, Secretary

Jack W. Carlson, Assistant Secretary-Energy and Minerals

BUREAU OF MINES

Thomas V. Falkie, Director DISTRIBUTION OF THIS DOCURENT UNLIMITED

Research at the Tuscaloosa Metallurgy Research Laboratory is carried out under a cooperative agreement between the Bureau of Mines, U.S. Department of the Interior, and the University of Alabama. 
This publication has been cataloged as follows:

\section{Goode, Alan $\mathrm{H}$}

Substitution of phosphate slime for bentonite in geothermal well drilling fluids, by Alan $\mathrm{H}$. Goode and Leon Y. Sadler III. [Washington] U.S. Bureau of Mines [1975]

8 p. tables. (U.S. Bureau of Mines. Report of investigations 8032)

Includes bibliography.

Based on work done in cooperation with the University of Alabama.

1. Drilling muds. 2. Bentonite. 3. Geothermal engineering. I. Sadler, Leon Y., jt. auth. II. U.S. Bureau of Mines. III. University of Alabama. IV. Title. V. Title: Phosphate slime. (Series)

TN23.U7 no. $8032 \quad 622.06173$

U.S. Dept. of the Int. Library 


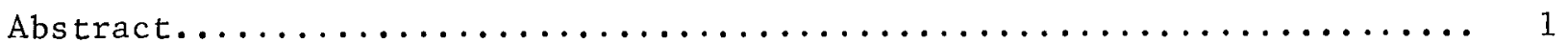

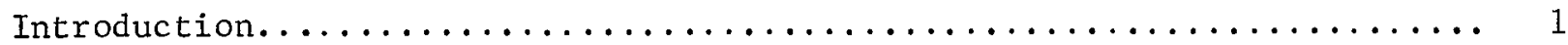

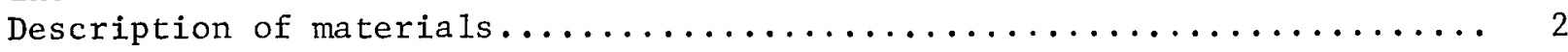

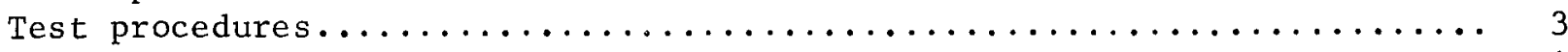

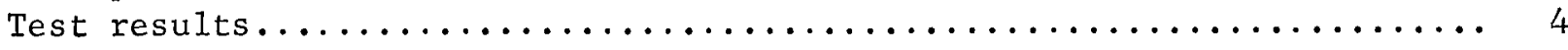

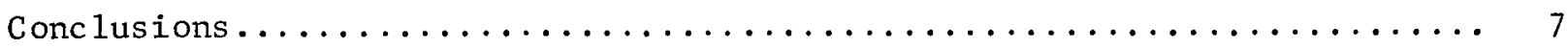

References........................................... 8

\section{TABLES}

1. Rheologic and filtration characteristics of bentonite, attapulgite, and phosphate slime suspensions in water and saturated $\mathrm{NaC} 1 \ldots \ldots . .4$

2. Effect of saline conditions on rheologic and filtration characteristics of bentonite and phosphate slime suspensions...... 5

3. Constituents of standard and experimental geothermal drilling

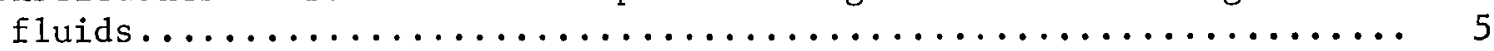

4. Effect of salts on rheologic and filtration characteristics of standard and experimental fluids..................... 6

5. Effects of temperature aging on rheologic and filtration characteristics of standard and experimental fluids............ 


\title{
SUBSTITUTION OF PHOSPHATE SLIME FOR BENTONITE IN GEOTHERMAL WELL DRILLING FLUIDS
}

\author{
by
}

Alan H. Goode ' and Leon Y. Sadler $\mathrm{II}^{2}$

\begin{abstract}
The advancement of high-temperature drilling fluid technology for application in geothermal environments is part of the Bureau of Mines program for more efficient development of our Nation's energy resources. The bentonite constituent of water-base drilling fluids is sensitive to destabilization by high-temperature and salinity. A substitute material for bentonite, phosphate slime, which is reported to be saline resistant, was considered. These studies show that spray-dried slime suspensions have more favorable rheological behavior, but poorer filtration properties, as compared with bentonite suspensions.
\end{abstract}

\section{INTRODUCTION}

In recent statements on U.S. energy policy, the President singled out the tapping of geothermal resources as one possible way to lessen the Nation's growing fuel and power shortage (9).$^{3}$ To help develop these resources the Tuscaloosa (Ala.) Metallurgy Research Laboratory of the Bureau of Mines has initiated research in the development of stable drilling fluids that would perform satisfactorily in the high-temperature environments encountered in drilling geothermal wells.

While conventional clay-lignite water suspensions used in drilling geotherma 1 we $11 \mathrm{~s}$ are limited in use to temperatures below $500^{\circ} \mathrm{F}$ (ㅁ) , temperatures often exceed $600^{\circ} \mathrm{F}$, and salinities can exceed $250,000 \mathrm{ppm}$ ( $\underline{6}$ ). New fluid compositions are thus required that resist destabilization under these conditions. Genera11y, clay-lignite water-base fluids are favored for geothermal applications because of being more compatible with related geological formations, and less expensive than oil-base muds when employed in areas where lost circulation is a problem. The bentonite clay constituent of this fluid suspension is sensitive to destabilization by high temperature and salinity.

${ }^{1}$ Minerals engineer

${ }^{2}$ Chemical engineer.

${ }^{3}$ Underlined numbers in parentheses refer to the list of references at the end of this report. 
Research was focused on finding a substitute for bentonite. A colloidal waste material, phosphate slime, which was reported to be saline resistant ( $\underline{7}$ ), was therefore considered.

This report covers preliminary studies on testing phosphate slime as a substitute for bentonite in geothermal drilling fluids. One of the attractive properties of phosphate slime is its apparent resistance to settling ( 2 , pp. 16-17). Rheology and filtration characteristics of two standard clay materials, bentonite, and attapulgite, are compared with a sample of Florida phosphate slime. Also, standard and experimental drilling muds using these materials are compared.

\section{DESCRIPTION OF MATERIALS}

Bentonite and attapulgite are the two principal colloidal clay materials used, in compounding water-base drilling fluids, to impart thixotropy to the suspension. Samples of these clays (each having a yield ${ }^{4}$ of 90 ) were obtained commercially for testing.

Montmorillonite is the primary clay mineral constituent of bentonite. The individual clay particles are thin, flat sheets stacked in micalike layers. These layers separate in water, generating a high-surface-area suspension. The flat particle shape is reported to be responsible for thixotropy and fi1tration control in a drilling fluid. Montmorillonite, however, is easily flocculated by soluble salts (1, p. 22).

The attapulgite clay mineral exists as needlelike particles that intermesh in water suspensions and are highly resistant to flocculation by soluble salts. However, as a result of particle shape and entanglement, attapulgite suspensions provide poor filtration control in a drilling fluid (1, p. 22).

The phosphate slime used in this study was obtained from a phosphate producer in central Florida. X-ray analysis of this material showed the following to be the principal mineral constituents in descending order of occurrence: apatite, montmorillonite attapulgite, quartz, and kaolinite. Spray-drying the phosphate slime was deemed most attractive from a materialshandling standpoint. This drying technique produced a free-flowing powder with a minimum of processing. Prior to spray-drying, the sample was screened on a 150-mesh vibrating screen to remove tramp materials that would plug the spray-dryer atomizing nozzle. The spray-dryer was operated at an inlet gas temperature of $617^{\circ} \mathrm{F}$ and an outlet gas temperature of $257^{\circ} \mathrm{F}$.

According to Grim (3), adsorbent water loss below $662^{\circ} \mathrm{F}$ for attapulgite and interlayer water loss below $734^{\circ} \mathrm{F}$ for montmorillonite should be easily regained. Thus the mineral structure of the phosphate slime was not altered by the spray-drying process. The slime when reconstituted with water was found to have a yield of 67 , which is 23 barrels of mud per ton of material less than the bentonite or attapulgite.

${ }^{4}$ Yield is the number of barrels of mud having a viscosity of 15 centipoise which can be prepared from 1 ton of dry clay. 


\section{TEST PROCEDURES}

Viscosity, gel strength, 5 and filtration characteristics were used to evaluate the behavior of al1 fluid suspensions. These measurements were made according to the recommended procedure of the American Petroleum Institute. ${ }^{6}$ All viscosity and gel strength measurements were made at room temperature using a variable-speed rotational-bob viscometer.

The rheology of drilling fluids is generally non-Newtonian in nature; that is, viscosity of the fluid is a function of shear rate. Thus, a nonNewtonian drilling fluid will have different viscosities, depending on the flow conditions in the drill pipe, bit, and annulus. Optimum viscosities of drilling fluids are as follows: For good hole cleaning (removal of cuttings), a high viscosity $\left(100 \mathrm{cp}, 100 \mathrm{sec}^{-1}\right.$ ) is needed in the greater part of the cross section of the annulus. However, for hole stability and faster drilling rates, a low-viscosity (10 cp, $1,000 \mathrm{sec}^{-1}$ ) fluid is most desirable ( $\left.\underline{8}\right)$. When circulation ceases, viscosity should be high enough to keep drill cuttings suspended.

In the Bingham rheological equation of state (generally used to describe flow behavior of drilling fluids), rheology is described in terms of two quantities: plastic viscosity $(\overline{\mathrm{PV}})^{7}$ and yield point $(\overline{\mathrm{YP}}) .8$ A liquid with a zero yield point is Newtonian, while the more non-Newtonian the fluid, the higher the $\overline{\mathrm{YP}} / \overline{\mathrm{PV}}$ ratio (4).

To determine high-temperature effects on flow properties, samples were aged at $565^{\circ} \mathrm{F}$ for 18 hours in a continuously agitated pressurized vessel. Filtration tests on fluid samples were conducted at ambient temperatures and at $500^{\circ} \mathrm{F}$. Differential pressures across the filter cake of 100 and 500 psi were maintained during the respective filtration tests.

Satisfactory filtration behavior is vital to a mud's successful performance. A primary function of the mud is to seal porous formations, to minimize the flow of mud or mud filtrate from the borehole into the pores of the formation. Therefore, a mud with good filtration characteristics will develop a thin impermeable filter cake around the perimeter of the borehole. Mud filtration behavior downhole is estimated in the testing laboratory (according to API procedures) by measuring the filtrate loss and cake thickness at a specified temperature and differential pressure across a screen of known diameter during a specified test period. Before measurements were made, al1 fluids were mixed with a high-speed mixer for 15 minutes and tested imme diate ly.

5 Ge1 strength is the minimum shearing stress that will produce permanent deformation of the colloidal suspension. It is a measure of the attractive forces in the drilling fluid under static conditions.

${ }^{6}$ American Petroleum Institute. Standard Procedure for Testing Drilling Fluids. RP 13B, 4th ed., November 1972 , pp. 3-10.

$7 \overline{\mathrm{PV}}$, expressed in centipoise, is indicative of the concentration, shape, and size of solids in the drilling fluid.

$8 \overrightarrow{\mathrm{YP}}$, expressed in pounds per hundred square feet, is indicative of the degree of dispersion or attraction between the particles in the drilling fluid. 


\section{TEST RESULTS}

Viscosity, gel strength, and filtration properties of bentonite, attapulgite, and phosphate slime suspensions were measured in fresh water and a saturated NaC1 brine environment at ambient temperature. Test results, presented in table 1 , indicated that slime and attapulgite in fresh water and brine environments were appreciably more non-Newtonian in character than bentonite, especially at the higher solids concentration, as evidenced by the higher $\overline{\mathrm{YP}} / \mathrm{PV}$ ratio. Higher ratios mean better hole cleaning and penetration rates, as long as gel strengths are not excessively high (ge1 strengths between 10 and $501 \mathrm{~b} / 100 \mathrm{ft}^{2}$ are acceptable). Filtration tests ( 100 psi differential) showed that of the three materials, bentonite had the only good filtration behavior (low fluid loss and thin filter cake) in a fresh water environment. All three materials showed poor filtration characteristics in a brine environment.

TABLE 1. - Rheologic and filtration characteristics of bentonite, attapulgite, and phosphate slime suspensions in water and saturated NaCl brine

\begin{tabular}{|c|c|c|c|c|c|c|c|c|}
\hline & \multicolumn{4}{|c|}{ Bentonite } & \multicolumn{4}{|c|}{ Phosphate slime } \\
\hline & \multicolumn{2}{|c|}{ Test 1} & \multicolumn{2}{|c|}{ Test 2} & \multicolumn{2}{|c|}{ Test 1} & \multicolumn{2}{|c|}{ Test 2} \\
\hline & Water & Brine & Water & Brine & Water & Brine & Water & Brine \\
\hline Concentration.............. Ib/bbl.. & 20 & 20 & 30 & 30 & 20 & 20 & 30 & 30 \\
\hline$\overline{\mathrm{PV}} . \ldots \ldots \ldots \ldots \ldots \ldots \ldots \ldots \ldots \ldots$ & 8 & 12 & 45 & 13 & 6 & 8 & 4 & 6 \\
\hline$\overline{\mathrm{YP}} \ldots \ldots \ldots \ldots \ldots \ldots \ldots 1 \mathrm{~b} / 100 \mathrm{ft} \mathrm{t}^{2} \ldots$ & 2 & 4 & 45 & 4 & 5 & 5 & 21 & 23 \\
\hline 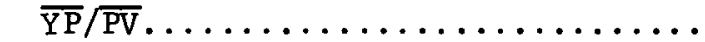 & 0.25 & 0.33 & 1 & 0.31 & 0.83 & 0.62 & 5.3 & 3.8 \\
\hline 10 -sec gel strength $. .1 \mathrm{~b} / 100 \mathrm{ft}^{2} .$. & 1 & 1 & 21 & 1 & 4 & 4 & 13 & 12 \\
\hline 10 -min gel strength...1b/100 $\mathrm{ft}^{2} \ldots$ & 2 & 1 & 36 & 1 & 5 & 4 & 13 & 12 \\
\hline Apparent viscosity ${ }^{1} \ldots \ldots \ldots \ldots$. & 10 & 14 & 68 & 15 & 8 & 10 & 14 & 17 \\
\hline \multicolumn{9}{|l|}{ Filtration properties: } \\
\hline Filtrate........... & 12 & 166 & 8 & 152 & 113 & 146 & 101 & 103 \\
\hline \multirow[t]{4}{*}{ Cake thickness............ inch.. } & $2 / 32$ & $5 / 32$ & $3 / 32$ & $4 / 32$ & $5 / 32$ & $7 / 32$ & $7 / 32$ & $6 / 32$ \\
\hline & \multicolumn{4}{|c|}{ Attapulgite } & & & & \\
\hline & \multicolumn{2}{|c|}{ Test 1} & \multicolumn{2}{|c|}{ Test 2} & & & & \\
\hline & Water & Brine & Water & Brine & & & & \\
\hline \multirow{2}{*}{\multicolumn{6}{|c|}{$\begin{array}{l}\text { Rheologic properties: } \\
\overline{\text { PV }} . \ldots \ldots \ldots \ldots \ldots \ldots \ldots \ldots \ldots \ldots \ldots \text {. }\end{array}$}} & & & \\
\hline & 6 & 6 & 15 & 15 & & & & \\
\hline$\overline{\mathrm{YP}} \ldots \ldots \ldots \ldots \ldots \ldots \ldots \ldots \mathrm{ft}^{2} \ldots$ & 30 & 13 & 95 & 58 & & & & \\
\hline$\overline{\mathrm{YP}} / \overline{\mathrm{PV}}, \ldots \ldots \ldots \ldots \ldots \ldots \ldots \ldots \ldots \ldots$ & 5 & 2.8 & 6.3 & 3.9 & & & & \\
\hline 10 -sec gel strength...1b/100 $\mathrm{ft}^{2} \ldots$ & 20 & 7 & 64 & 34 & & & & \\
\hline 10 -min ge 1 strength...1b/100 $\mathrm{ft}^{2} \ldots$ & 25 & 12 & 64 & 54 & & & & \\
\hline Apparent viscosity $\ldots \ldots \ldots \ldots$. cp. & 21 & 13 & 62 & 44 & & & & \\
\hline \multicolumn{9}{|l|}{ Filtration properties: } \\
\hline Filtrate.$\ldots \ldots \ldots \ldots \ldots \ldots$ ml. & 97 & 116 & 80 & 80 & & & & \\
\hline Cake thickness. . . . . . . . . . inch.. & $6 / 32$ & $6 / 32$ & $8 / 32$ & $8 / 32$ & & & & \\
\hline
\end{tabular}

Effects of saline conditions on rheologic and filtration properties were determined, and results are presented in table 2 . These data revealed that CaO produced 
the more severe effects in both suspensions. In the presence of $\mathrm{CaO}$, bentonite formed a tenacious gel and gave a large volume of filtrate (100 psi differential) and thick filter cake. Rheologic properties of the slime were acceptable, while its filtration properties were severly degraded. With $\mathrm{CaSO}_{4}$ contamination, $\overline{\mathrm{YP}} / \overline{\mathrm{PV}}$ ratio for bentonite increased more than five times over that of the noncontaminated sample, while the ratio for the slime only doubled. Both bentonite and slime suspensions have acceptable rheologic properties at the contaminant concentration levels tested. Similarly, filtration (100 psi differential) properties of both bentonite and slime suspensions were impaired by the $\mathrm{CaSO}_{4}$.

TABLE 2. - Effect of saline conditions on rheologic and filtration characteristics of bentonite and phosphate slime suspensions

\begin{tabular}{|c|c|c|c|c|c|c|c|c|c|c|}
\hline \multirow[b]{3}{*}{ Salt concentration........1b/bb1.. } & \multicolumn{5}{|c|}{ Bentonite ${ }^{1}$} & \multicolumn{5}{|c|}{ Phosphate slime } \\
\hline & \multirow{2}{*}{$\begin{array}{r}\begin{array}{l}\text { Con- } \\
\text { trol }\end{array} \\
0\end{array}$} & \multicolumn{2}{|c|}{$\mathrm{CaO}$} & \multicolumn{2}{|c|}{$\mathrm{CaSO}_{4}$} & \multirow{2}{*}{$\begin{array}{l}\text { Con- } \\
\text { trol } \\
0\end{array}$} & \multicolumn{2}{|c|}{$\mathrm{CaO}$} & \multicolumn{2}{|c|}{$\mathrm{CaSO}_{4}$} \\
\hline & & 10 & 20 & 10 & 20 & & 10 & $\overline{20}$ & 10 & $\overline{20}$ \\
\hline Rheologic properties: & & & & & & & & & & \\
\hline$\overline{\mathrm{PV}} \ldots \ldots \ldots \ldots \ldots \ldots$ & 45 & (e) & (a) & 11 & 8 & 4 & 10 & 10 & 7 & 10 \\
\hline$\overline{Y P} \ldots \ldots \ldots \ldots \ldots \ldots \ldots 1 b / 100 \mathrm{ft}^{2} \ldots$ & 45 & (e) & $\left({ }^{2}\right)$ & 26 & 43 & 21 & 135 & 100 & 44 & 105 \\
\hline$\overline{\mathrm{YP}} / \overline{\mathrm{PV}} \ldots \ldots \ldots \ldots \ldots$ & 1 & (2) & $\left({ }^{2}\right)$ & 2.36 & 5.38 & 5.25 & 13.5 & 10 & 6.29 & 10.5 \\
\hline $10-\sec$ gel strength..1b/100 $\mathrm{ft}^{2}$ & $2 \overline{1}$ & (e) & (e) & 19 & 28 & 13 & 22 & 20 & 24 & 40 \\
\hline 10 -min gel strength..1b/100 $\mathrm{ft}^{2}$ & 36 & (2) & $\left({ }^{2}\right)$ & 26 & 32 & 13 & 25 & 20 & 20 & 34 \\
\hline Apparent viscosity $\ldots \ldots \ldots \ldots$. & 68 & $\left({ }^{2}\right)$ & (e) & 24 & 29 & 14 & 77 & 60 & 29 & 62 \\
\hline Filtration properties: & & & & & & & & & & \\
\hline Filtrate.............. & 8 & 66 & 72 & 40 & 47 & 101 & 308 & 348 & 120 & 130 \\
\hline Cake thickness............. inch. & $3 / 32$ & & & $7 / 32$ & $8 / 32$ & $7 / 32$ & & & $11 / 32$ & $12 / 32$ \\
\hline
\end{tabular}

Concentration of 30-pound-per-barrel.

${ }^{2} \mathrm{Gel}$, too viscous to measure.

Table 3 shows the constituents of each drilling fluid tested. A11 were waterbased, colloidal clay-lignite, but the amounts of reagents present differed.

TABLE 3. - Constituents of standard ${ }^{1}$ and experimenta 1 geothermal drilling fluids

\begin{tabular}{|c|c|c|c|c|}
\hline \multirow{3}{*}{ Constituents } & \multicolumn{4}{|c|}{ Pounds per barrel of each constituent ${ }^{2}$} \\
\hline & \multicolumn{2}{|c|}{ Standard fluids } & \multicolumn{2}{|c|}{ Experimental fluids } \\
\hline & I & II & III & IV \\
\hline Phosphate slime.. & 0 & 0 & 0 & 20 \\
\hline Bentonite $\ldots \ldots \ldots \ldots \ldots \ldots \ldots$ & 6 & 32 & 20 & 0 \\
\hline Lignite $\ldots \ldots \ldots \ldots \ldots \ldots \ldots \ldots$ & 30 & 14 & 10 & 10 \\
\hline $\mathrm{NaOH}, \ldots \ldots \ldots \ldots \ldots \ldots \ldots \ldots \ldots$ & 3 & 1 & 3 & 3 \\
\hline Barite $\ldots \ldots \ldots \ldots \ldots \ldots \ldots \ldots$ & 19 & 218 & 0 & 0 \\
\hline $\mathrm{Na}_{2} \mathrm{CO}_{3} \ldots \ldots \ldots \ldots \ldots \ldots \ldots \ldots \ldots$ & 3 & 2 & 0 & 0 \\
\hline $\mathrm{NaBiO}_{3} \ldots \ldots \ldots \ldots \ldots \ldots \ldots \ldots \ldots$ & 0 & 0 & 2 & 2 \\
\hline Polyacrylate................. & 0 & 0 & 0.33 & 0.33 \\
\hline Actaflo-s.................. & 6 & 10 & 0 & 0 \\
\hline $\mathrm{NaC} 1, \ldots \ldots \ldots \ldots \ldots \ldots \ldots \ldots$ & 0.5 & 0.6 & 0 & 0 \\
\hline No. 2 diese 1 oil $\ldots \ldots \ldots \ldots \ldots$ & 0 & 2 & 0 & 0 \\
\hline
\end{tabular}

ITypes of compositions described in the literature, which have been used to drill geothermal wells.

${ }^{2}$ Each composition contained the given pounds-per-barrel of dried material added to 42 gal (1 barre1) of water. 
Ten pounds per barrel of each salt $\left(\mathrm{CaO}, \mathrm{CaSO}_{4}\right.$, and $\mathrm{NaCl}$ were added separately to each fluid in table 3 . Table 4 shows the effect of these salts on rheologic and filtration properties of muds. Standard ${ }^{9}$ fluid I proved to be most resistant to salts. In general, $\mathrm{CaSO}_{4}$ had the most pronounced detrimental effect. The slime-lignite fluid IV was the most sensitive to salt effects, as evidenced by the higher $\overline{\mathrm{YP}} / \overline{\mathrm{PV}}$ ratio and poorer filtration (100 psi differential). The overall rheologic behavior of this fluid is attractive because the gel strengths are not excessively high. The standard fluids, however, showed better filtration characteristics than either experimental fluid.

TABLE 4. - Effects of salts ${ }^{1}$ on rheologic and filtration characteristics of standard and experimenta 1 fluids

\begin{tabular}{|c|c|c|c|c|c|c|c|c|}
\hline & \multicolumn{4}{|c|}{ Standard fluid I } & \multicolumn{4}{|c|}{ Standard fluid II } \\
\hline & None & $\mathrm{CaO}$ & $\mathrm{CaSO}_{4}$ & $\mathrm{NaC1}$ & None & $\mathrm{CaO}$ & $\mathrm{CaSO}_{4}$ & $\mathrm{NaC1}$ \\
\hline \multicolumn{9}{|l|}{ Rheologic properties: } \\
\hline$\overline{P V} \ldots \ldots \ldots \ldots \ldots \ldots \ldots \ldots \ldots \ldots$ & 5 & 7 & 16 & 7 & 16 & 65 & 65 & 46 \\
\hline$\overline{\mathrm{YP}} \ldots \ldots \ldots \ldots \ldots \ldots \ldots \mathrm{Lb} / 100 \mathrm{f \textrm {t } ^ { 2 }} \ldots$ & 0 & 0 & 44 & 0 & 0 & 120 & 210 & 38 \\
\hline$\overline{\mathrm{YP}} / \overline{\mathrm{PV}} \ldots \ldots \ldots \ldots \ldots \ldots \ldots \ldots$ & 0 & 0 & 2.75 & 0 & 0 & 1.85 & 3.23 & 0.83 \\
\hline 10 -sec ge1 strength...1b/100 $\mathrm{ft}^{2} \ldots$ & 2 & 1 & 9 & 1 & 2 & 160 & 80 & \\
\hline 10-min gel strength..1b/100 $\mathrm{ft}^{2} \ldots$ & 1 & 1 & 34 & 1 & 2 & 230 & 110 & 14 \\
\hline Apparent viscosity............ & 5 & 7 & 38 & 6 & 16 & 125 & 170 & 65 \\
\hline \multicolumn{9}{|l|}{ Filtration properties: } \\
\hline \multirow{4}{*}{ 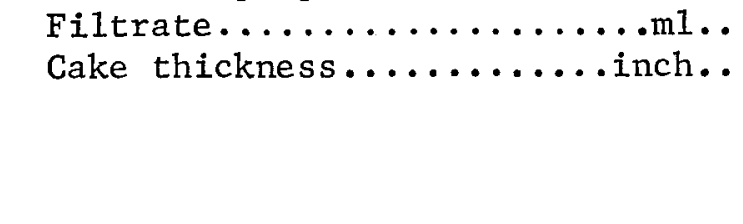 } & 2 & 6 & 16 & 3 & 3 & 11 & 17 & \\
\hline & $1 / 32$ & $3 / 32$ & $5 / 32$ & $1 / 32$ & $2 / 32$ & $5 / 32$ & $5 / 32$ & $2 / 32$ \\
\hline & \multicolumn{4}{|c|}{$\begin{array}{l}\text { Experimental } \\
\text { fluid III }\end{array}$} & \multicolumn{4}{|c|}{$\begin{array}{l}\text { Experimental } \\
\text { fluid IV }\end{array}$} \\
\hline & None & $\mathrm{CaO}$ & $\mathrm{CaSO}_{4}$ & $\mathrm{NaC1}$ & None & $\mathrm{CaO}$ & $\mathrm{CaSO}_{4}$ & $\widehat{\mathrm{NaCl}}$ \\
\hline \multicolumn{9}{|l|}{ Rheologic properties: } \\
\hline 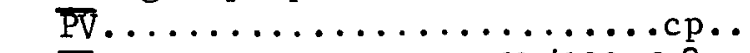 & 19 & 120 & 130 & 29 & 9 & 10 & 35 & \\
\hline$\overline{\mathrm{YP}} \ldots \ldots \ldots \ldots \ldots \ldots \ldots \mathrm{lb} / 100 \mathrm{ft}^{\overline{2}} \ldots$ & & 40 & 170 & 16 & 3 & 100 & 90 & 24 \\
\hline$\overline{\mathrm{YP}} / \overline{\mathrm{PV}} \ldots \ldots \ldots \ldots \ldots \ldots \ldots \ldots \ldots$ & 0.19 & 0.33 & 1.31 & 0.55 & 0.33 & 10 & 2.57 & 2.67 \\
\hline $10-$ sec gel strength...1b/100 $\mathrm{ft}^{2} \ldots$ & 1 & 80 & 100 & 9 & 1 & 26 & 19 & 19 \\
\hline 10 -min gel strength..1b/100 $\mathrm{ft}^{2} .$. & 5 & 140 & 70 & 20 & 3 & 42 & 16 & 35 \\
\hline Apparent viscosity $\ldots \ldots \ldots \ldots$.... & 20 & 140 & 215 & 37 & 10 & 60 & 80 & 21 \\
\hline \multicolumn{9}{|l|}{ Filtration properties: } \\
\hline 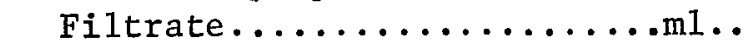 & & 44 & 34 & 11 & 7 & 97 & 59 & 14 \\
\hline Cake thickness............ & $1 / 32$ & $3 / 32$ & $5 / 32$ & $2 / 32$ & $1 / 32$ & $4 / 32$ & $6 / 32$ & $2 / 32$ \\
\hline
\end{tabular}

High-temperature effects on rheologic and filtration properties of each fluid in table 3 were measured. Results in table 5 showed flow behavior of all fluids to essentially withstand temperature degradation, except for

9 Types of compositions described in the literature, which have been used to drill geothermal wells. 
increased thixotropy of standard fluid II as reflected in its higher ge 1 strength after aging. The bentonite-lignite experimental fluid III showed the most favorable filtration behavior, while the other fluids had excessively high filtrate volume and/or excessively thick filter cakes.

TABLE 5. - Effects of temperature aging ${ }^{1}$ on rheologic and filtration characteristics of standard and experimental fluids

\begin{tabular}{|c|c|c|c|c|}
\hline & \multicolumn{4}{|c|}{ Standard } \\
\hline & \multicolumn{2}{|c|}{ I } & \multicolumn{2}{|c|}{ II } \\
\hline & Before & After & Before & After \\
\hline \multicolumn{5}{|l|}{ Rheologic properties: } \\
\hline 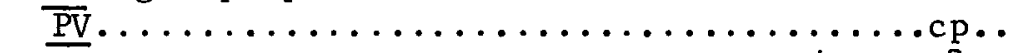 & 5 & 6 & 16 & 35 \\
\hline$\overline{\mathrm{YP}} \ldots \ldots \ldots \ldots \ldots \ldots \ldots \ldots \ldots \ldots \ldots \ldots \ldots \mathrm{ft}^{\mathrm{z}} \ldots$ & 0 & 0 & 0 & 35 \\
\hline 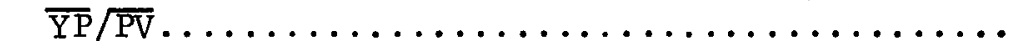 & 0 & 0 & 0 & 1 \\
\hline $10-\sec$ gel strength............. & 2 & 1 & 2 & 50 \\
\hline 10-min gel strength............ & 1 & 3 & 2 & 80 \\
\hline Apparent viscosity $\ldots \ldots \ldots \ldots \ldots \ldots \ldots \ldots \ldots$ & 5 & 6 & 16 & 52 \\
\hline Filtration properties: & & & & \\
\hline \multirow{4}{*}{ 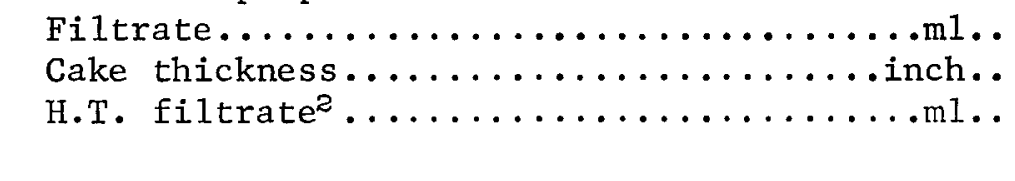 } & 2 & 33 & 3 & 22 \\
\hline & $1 / 32$ & $6 / 32$ & $2 / 32$ & $6 / 32$ \\
\hline & 20 & & 238 & \\
\hline & \multicolumn{4}{|c|}{ Experimenta 1} \\
\hline & \multicolumn{2}{|c|}{ III } & \multicolumn{2}{|l|}{ IV } \\
\hline & Before & After & Before & After \\
\hline \multicolumn{5}{|l|}{ Rheologic properties: } \\
\hline$\underline{\mathrm{PV}} \ldots \ldots \ldots \ldots \ldots$ & 19 & 31 & 9 & 11 \\
\hline$\overline{Y P} \ldots \ldots \ldots \ldots \ldots$ & 3 & 0 & 3 & 14 \\
\hline$\overline{\mathrm{YP}} / \overline{\mathrm{PV}} \ldots \ldots \ldots \ldots \ldots \ldots \ldots \ldots \ldots \ldots \ldots \ldots \mathrm{ft}^{2} \ldots \ldots$ & 16 & 0 & 0.33 & 1.27 \\
\hline $10-$ sec ge 1 strength............ & 1 & 1 & 1 & 6 \\
\hline $10-\min$ gel strength............ & 5 & 1 & 3 & 5 \\
\hline Apparent viscosity $\ldots \ldots \ldots \ldots \ldots \ldots \ldots \ldots \ldots$. & 20 & 27 & 10 & 18 \\
\hline \multicolumn{5}{|l|}{ Filtration properties: } \\
\hline 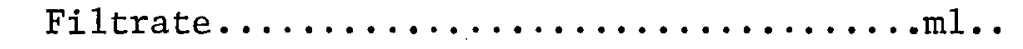 & 7 & 9 & 7 & 30 \\
\hline Cake thickness....................... & $1 / 32$ & $1 / 32$ & $1 / 32$ & $3 / 32$ \\
\hline H.T. filtrate ${ }^{2} \ldots \ldots \ldots \ldots \ldots \ldots$ & 28 & & 270 & \\
\hline
\end{tabular}

${ }^{1}$ High temperature aged at $565^{\circ} \mathrm{F}$ for 18 hours.

${ }^{2} \mathrm{High}$-temperature filtration test, conducted at $500^{\circ} \mathrm{F}, \Delta \mathrm{P}=500 \mathrm{psi}$, 30 minutes.

\section{CONCLUSIONS}

Results of these initial studies indicated that phosphate slime-base drilling fluids have more favorable rheological behavior than bentonite-base fluids, but poorer filtration properties. Both attapulgite and phosphate slime-base fluids resisted flocculation in a saline environment, but exhibited poor filtration properties. Additional research is needed to improve filtration behavior in both attapulgite--and phosphate slime-base fluids. 


\section{REFERENCES}

1. Baroid Division, Nationa 1 Lead Co. Baroid Mud Technology Handbook. Houston, Tex., 1965, pp. 19, 22.

2. Boyle, J. R. Waste Disposal Costs of a Florida Phosphate Operation. BuMines IC 8404, 1969, pp 16-17.

3. Grim, R. E. Clay Mineralogy. McGraw-Hil1 Book Co., Inc., New York, $1953, \mathrm{pp} .230,244$.

4. Holman, W. E. Kelzan ${ }^{\mathrm{R}} \mathrm{XC}$, A Drilling Fluid System With Rheology Control. Kelco Co., Houston, Tex. P. 14.

5. Hutchinson, S. O., and G.W. Anderson. New Drilling Fluids Have Application in Geotherma1 Exploration. Standard Oil Co. of California, Oildale, Calif. 1971, p. 14.

6. Jaffe, F. C. Geothermal Energy, A Review. Bull. Ver. Schweiz. Petrol. Geol. u.-Ing, v. 38, No. 93, October 1971, pp. 25-26.

7. LaMer, V. K., and R. H. Smellie, Jr. Flocculation, Subsidence, and Filtration of Phosphate Slimes. J. Colloidal Sci., v. 11, 1956, p. 708 .

8. Walker, R. E. Drilling Fluid Rheology: Notes From the 1969 Kelco Drilling F1uid Seminars. Kelco Co., Houston, Tex.

9. Weismante1, G. Geothermal Power Still Iffy. Chem. Eng., v. 80, No. 7, 1973, p. 40 . 